\title{
The gut microbiome: the role of a virtual organ in the endocrinology of the host
}

\author{
James M Evans', Laura S Morris' and Julian R Marchesi ${ }^{1}{ }^{1,2}$ \\ ${ }^{1}$ School of Biosciences, Cardiff University, Cardiff CF10 3AX, UK \\ ${ }^{2}$ Department of Hepatology and Gastroenterology, Imperial College London, St Marys, Norfolk Place, \\ London W2 1NY, UK
}

Correspondence should be addressed to J R Marchesi

Email

marchesijr@cardiff.ac.uk

\begin{abstract}
The human microbiome contains a vast array of microbes and genes that show greater complexity than the host's own karyome; the functions of many of these microbes are beneficial and show co-evolution with the host, while others are detrimental. The microbiota that colonises the gut is now being considered as a virtual organ or emergent system, with properties that need to be integrated into host biology and physiology. Unlike other organs, the functions that the gut microbiota plays in the host are as yet not fully understood and can be quite easily disrupted by antibiotics, diet or surgery. In this review, we look at some of the best-characterised functions that only the gut microbiota plays and how it interacts with the host's endocrine system and we try to make it clear that the 21st-century biology cannot afford to ignore this facet of biology, if it wants to fully understand what makes us human.
\end{abstract}

\author{
Key Words \\ - human microbiome \\ - cross-talk \\ - gut microbiome \\ - endocrine system
}

\section{Introduction}

In the many years of studying the human body, it has become accepted that all the organs are known and well characterised in terms of their main functions. The whole discipline of anatomy has been focused on documenting the fine structure of these organs, while physiology and biochemistry have been determining their functions and specific chemical reactions. In the last 10 years, a significant revolution has been progressing, which started with the notion that for the best part of a hundred years we have been trying to describe how mammals function while ignoring one of the main organs in the body. However, this organ is not found or described in any conventional textbook and there are no clinical experts who can understand its functions and the pathologies that arise when it becomes diseased. This dearth of information is because this organ does not conform to the current definition of being an organ, i.e. 'a fully differentiated and functional unit', and should probably best be thought of as a virtual organ $\left(\mathrm{O}^{\prime}\right.$ Hara \& Shanahan 2006) since it is composed of microbes and all its functions are derived from these parts. In fact, it most probably should be considered as a system in the same way we look at our immune system, which is made of different cells, each having its own set of functions and roles. This paradigm shift is still undergoing some refinement, but it does beg the question 'what would biologists do if they were suddenly presented with a whole new organ/system?' Furthermore, why should we even think of it as an organ or system? To answer the last question first, we see this as a virtual organ/system due to the genetic and metabolic diversity that resides within it.

Microbiologists have coined a phrase for this system, the microbiome, which is defined as the the genetic

Published by Bioscientifica Ltd. 
material (DNA) within a microbial community'; this can also be referred to as the metagenome of the microbiota. The largest contributors to the human microbiome are the bacteria present in the intestinal tract, which have been estimated to be in the range of 100 trillion cells, ten times more cells than there are human cells in the host's body. In terms of the total non-redundant genetic load found in the human gut microbiome, it is 150 times larger than the host's karyome ((Qin et al. 2010), which is between 20000 and 26000 genes (Pennisi 2003, Collins et al. 2004)), and each individual has $\sim 540000$ bacterial genes in the gut (21-27 $\times$ the human karyome). While the karyome is generally regarded as fixed with respect to the gene catalogue, and at this stage ignoring any epigenetic mechanisms, the gut microbiome is far more random and each individual will contain a unique collection of microbes that are easily altered (see below). Humans are born either sterile or colonised with a very basic microbiome, and analysis of the meconium has shown that any microbes that are present are not necessarily those that ultimately colonise the adult gut (Koenig et al. 2011). The microbiome that is obtained is partly inherited from the mother and partly from the exposure to the environment in the first 2 years of life. Hence, there is a degree of determinism (both by exposure to the mother and due to genetic selection (Tims et al. 2013)) and also a significant proportion of random colonisation. However, it is striking that after 2 years of age, all adults' colons will be predominantly colonised with members of two phyla, namely Bacteroidetes: Gram-negative, anaerobic, non-spore-forming bacteria, which are enriched with carbohydrate-degrading enzymes, and Firmicutes: Grampositive, formerly called 'the low-GC bacteria', anaerobic, spore-forming bacteria, which ferment simple sugars to produce a variety of short-chain fatty acids (SCFAs), such as butyrate, acetate and propionate (Fischbach \& Sonnenburg 2011). Between them, these phyla can constitute over $90 \%$ of the bacteria present in the large intestinal lumen (Turnbaugh et al. 2009, Qin et al. 2010, Claesson et al. 2011, HMPC et al. 2012) and mucosa (Eckburg et al. 2005, Chen et al. 2012, Harrell et al. 2012), and the proportion of each phylum in the colon ranges from being nearly 90\% Firmicutes, at one end of the continuum, to $90 \%$ Bacteroidetes, at the other end. What dictates this distribution is unclear, and the consequences for the host are also unclear. Furthermore, our view of the intestinal environment is skewed towards the large intestine and is predominantly focused on faecal material, and even then we are very bacteria centric (Marchesi 2010). Bearing this biased view of the intestinal environment in mind, we have begun to determine what functions this collection of organisms plays in the host.

\section{A virtual organ/system with functions of importance to the host}

In the last 10 years, it has become increasingly apparent that the gut microbiota plays a significant role in host biology. We have a substantial body of evidence that these functions can be beneficial or detrimental to the host, and if they were assets, we would wish to maximise the former and somehow offset the latter. A significant portion of the evidence that supports a role for the gut microbiota in host development and function comes from studying sterile animals, especially rodents (Fig. 1). A recent comprehensive review of the use of such animals has shown how widespread the impact of not having a gut microbiota is (Smith et al. 2007). Some of the best studied of these bacterial functions include providing the host with energy in the form of SCFAs such as butyrate (Louis \& Flint 2009) and propionate (Macfarlane \& Macfarlane 2011), bile salt metabolism (Jones et al. 2008, Swann et al. 2011) and role in the brain-gut axis (Collins et al. 2012). Many ecological analyses of the colonic microbiota have shown that while it is relatively stable (Scanlan et al. 2006, Jalanka-Tuovinen et al. 2011, Kolmeder et al. 2012), it can be significantly perturbed by antibiotics (Dethlefsen et al. 2008, Jernberg et al. 2010), diet (Claesson et al. 2012, Ravussin et al. 2012) and surgery (Zhang et al. 2009, Li et al. 2011). Unlike a conventional organ, the functions of this virtual organ can be significantly altered or removed due to these environmental factors, which can result in disease in the host, e.g. Clostridium difficile-associated diarrhoea (Kachrimanidou \& Malisiovas 2011), or a significant alteration of the host's metabolite profile (Yap et al. 2008), the significance of which still remains unclear. The variability in the gut microbiome and its functions are important in two respects: the functions that one inherits and acquires are driven mainly by a random process and once established they can be perturbed by interventions.

\section{Bile metabolism and gut bacteria}

Bile acids/salts are cholesterol-derived host metabolites that play a role in several host processes (Fig. 2). Their principal functions are to aid in fat adsorption and prevent small intestinal bacterial overgrowth. Both these functions can be explained by the fact that bile acids are surfactants (not detergents), with a hydrophilic taurine or glycine group covalently bound to a hydrophobic steroid

Published by Bioscientifica Ltd. 


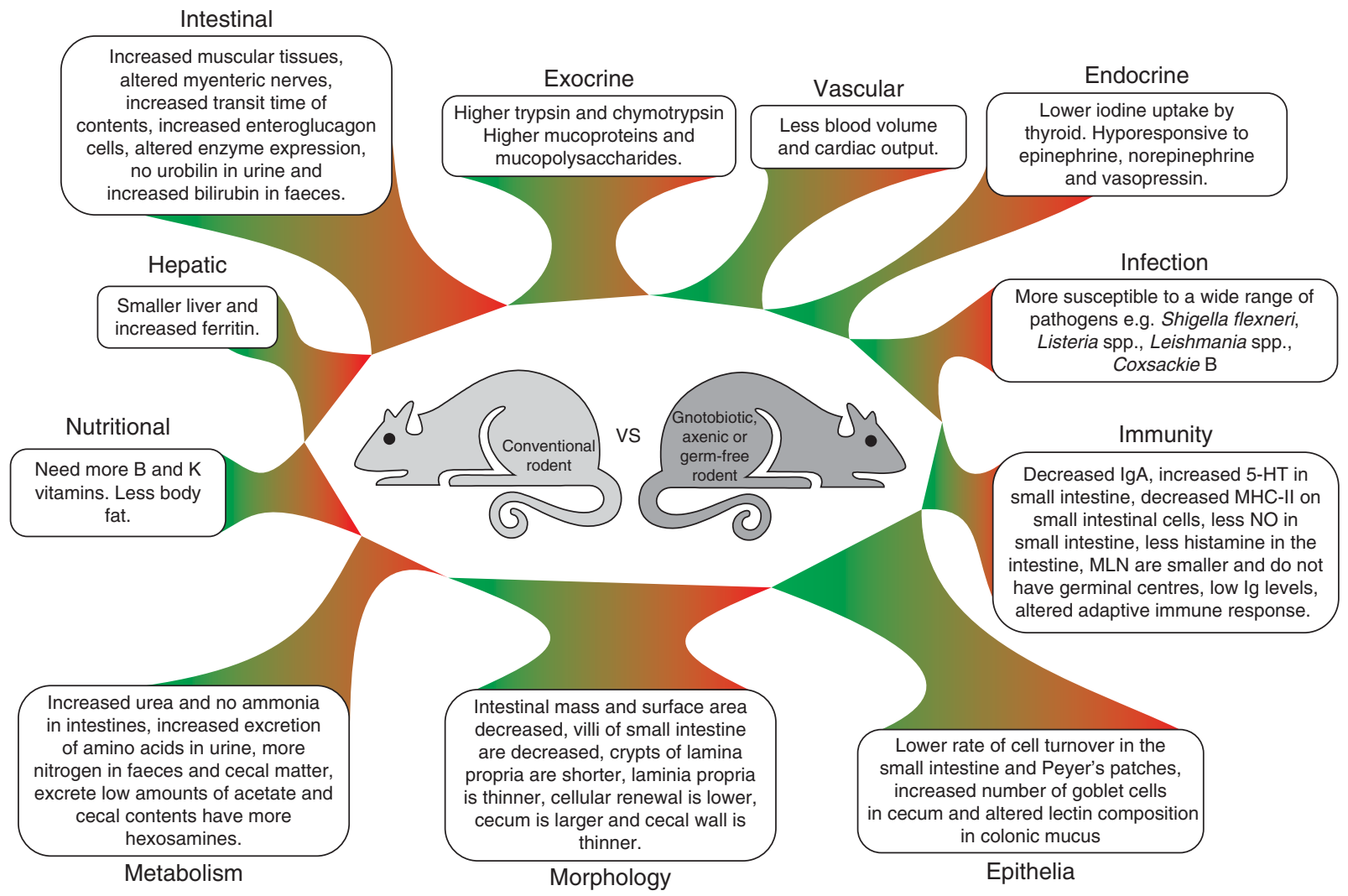

Figure 1

Schematic representation of areas of the rodent system that are significantly impacted by the absence of a normal microbiome; all the changes are those that are measured/observed in the sterile animal (adapted from Smith K,

(predominantly a $\mathrm{C}_{24}$ structure (Russell 2003))-derived moiety that is wholly derived from cholesterol. This surfactant nature allows them to associate with fat molecules to form micelles, which are ultimately absorbed by the host, thus facilitating fat metabolism. Additionally, being a surfactant allows them to be antimicrobial also, as they can disrupt the plasma membrane of the bacteria, causing them to lyse and die; thus in a niche where food is plentiful, bile helps to prevent the bacteria in the small intestine from overgrowing and becoming a health issue. A secondary role for bile involves regulating the host's cholesterol levels, on a typical day, $\sim 0.5 \mathrm{~g}$ of this steroid is used to synthesise bile acids in hepatocytes and accounts for $90 \%$ of the cholesterol usage (Russell 2003). Once the hormonal signal has been sent to the gall bladder, the bile acids are excreted into the small intestine, where they interact with the dietary lipids and fat-soluble vitamins. These complexes are eventually reabsorbed in the terminal ileum; this process is part of the enterohepatic circulation that ensures that $95 \%$ of the bile acids are recovered from the gut. The remaining 5\% that escapes this pathway
McCoy KD \& Macpherson AJ 2007 Use of axenic animals in studying the adaptation of mammals to their commensal intestinal microbiota. Seminars in Immunology 19 59-69. (doi:10.1016/j.smim.2006.10.002)).

enters the large intestine, where it becomes available for metabolism by bacteria. Interestingly, the gut bacteria have evolved several enzymes capable of modifying the primary bile acids such as the taurine- and glycineconjugated cholic and chenodeoxycholic acids and removing the taurine and glycine parts of the molecules to produce secondary bile salts, such as cholic, lithocholic and deoxycholic acids. While some of these secondary bile acids are excreted in the faeces, a significant proportion are passively absorbed and returned to the liver. These secondary bile acids then enter the enterohepatic circulation and the general bile metabolite pool. The bacterial enzymes responsible for the deconjugation of either taurine or glycine are collectively known as bile salt hydrolases (BSHs), choloylglycine hydrolases or bile acid hydrolases (EC 3.5.1.24) and catalyse the hydrolytic removal of taurine or glycine from the corresponding primary bile acids. However, as with many gut functions, the diversity and abundance of BSHs are highly variable as are their substrate ranges (Jones et al. 2008). Additionally, studies on germ-free rodents (i.e. sterile or gnotobiotic)

Published by Bioscientifica Lto. 


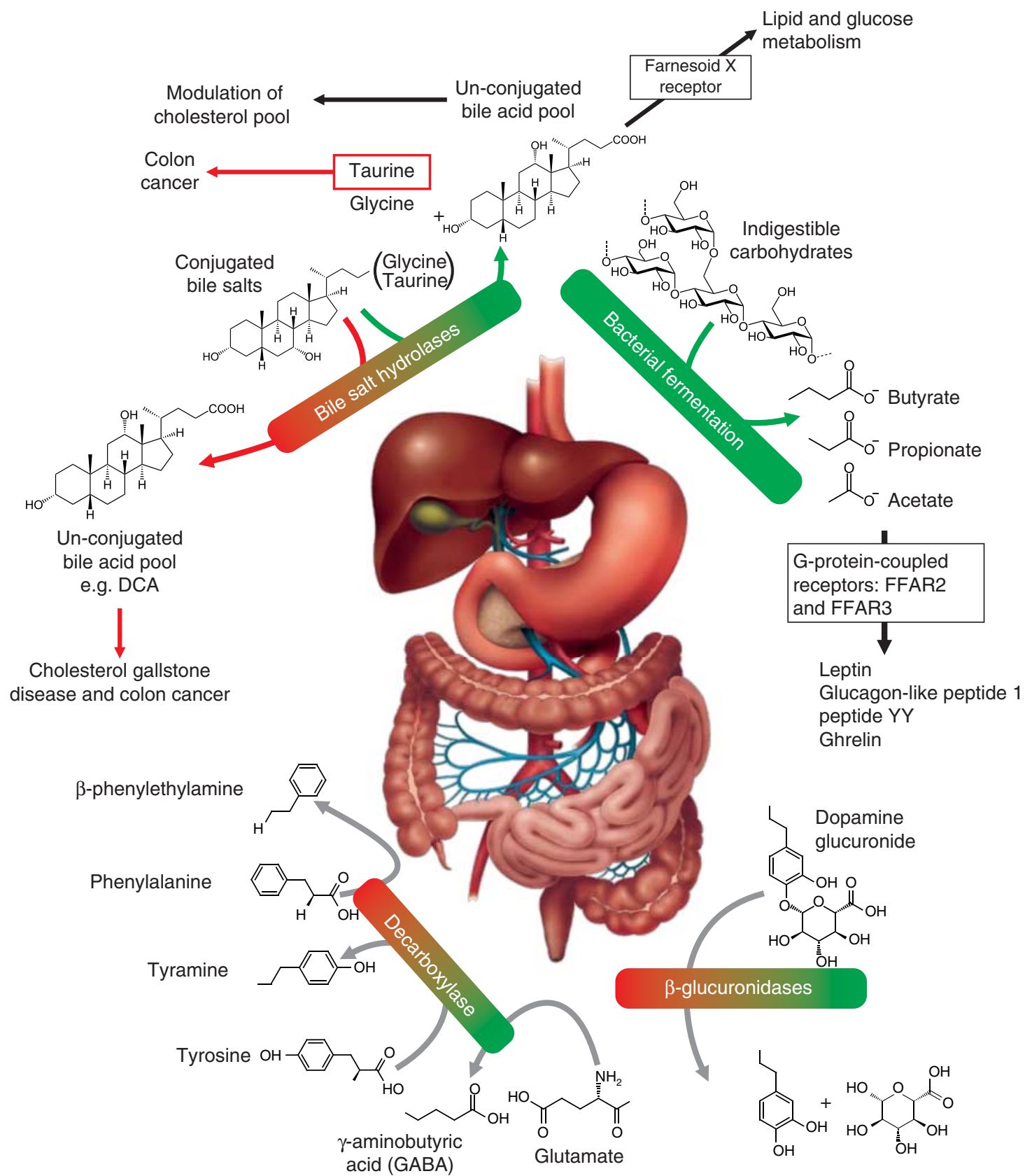

Figure 2

Schematic representation of some of the functions that the gut microbiota plays in the host. The four functions shown, those of bile salt hydrolases, bacterial fermentation, amino acid decarboxylases and glucuronidases, can

have shown that the bile pool is significantly and dramatically altered in other non-liver or non-gut compartments too, e.g. heart tissue (Fig. 3), which begs the question of the significance of having a specific BSH profile in the gut and the host's own physiology. Bile acids interact at an endocrinological level via three major signalling mechanisms, as ligands for the play a role in producing molecules that interact with the host's endocrine system. The red/green colour scheme implies that it is still unclear whether these functions are beneficial or detrimental to the host's physiology.

G-protein-coupled receptor $\mathrm{TGR}_{5}$, activators of the MAPK pathways and activators of the nuclear hormone receptors such as farnesoid X receptor $\alpha$ (FXR $\alpha$; NR1H4). While the primary bile acids are of significant interest as they have been shown to regulate lipid, energy and glucose metabolism, the secondary bile acids can also interact with these receptors. However, the availability of the

Published by Bioscientifica Ltd. 
A

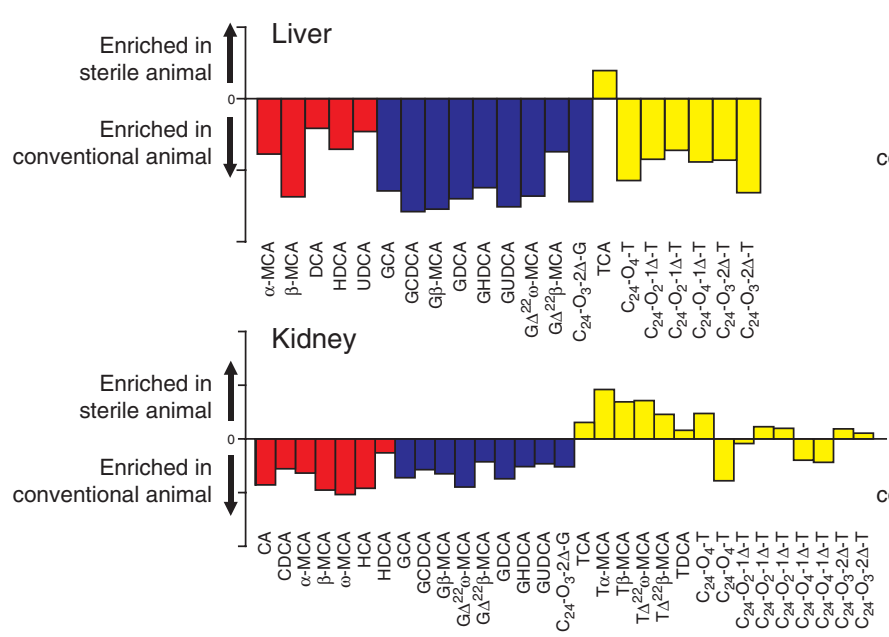

Glycine $\quad \square$ Taurine
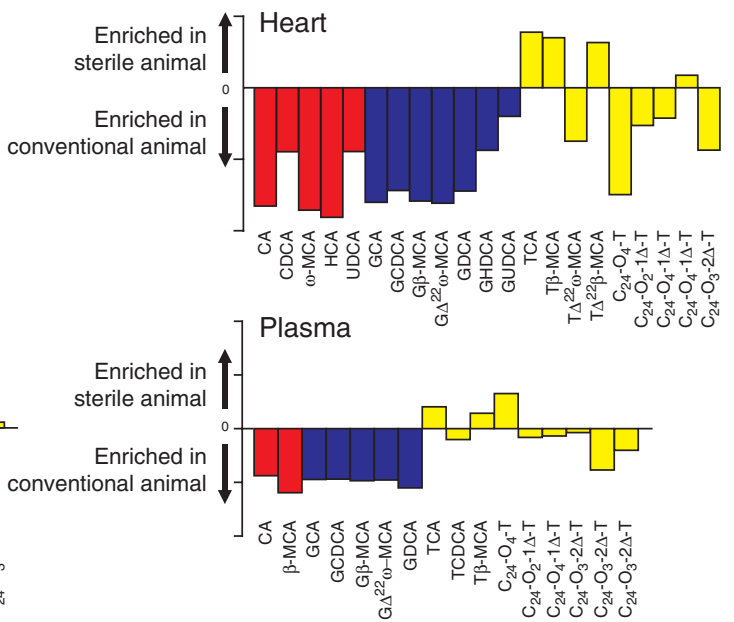

B
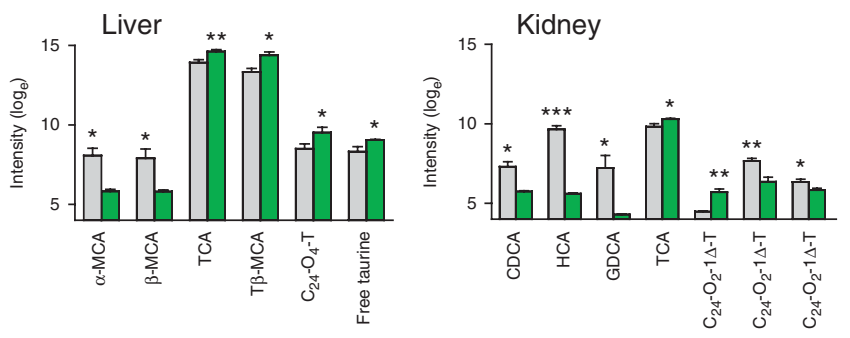

$\square$ Control
Antibiotic-treated
Figure 3

Differences in the bile profiles of sterile and normally colonised rats. (A) If the bar is above the origin (set at 0 ), the bile salt is enriched in the sterile animal when compared with the conventional animal and vice versa.

(B) Changes in bile metabolites when rats are treated with the antibiotics streptomycin and penicillin. (Values are means of the scaled data \pm s.E.M. Statistical significance was determined using Student's $t$-test. ${ }^{*} P<0.05$;

secondary bile acids is not as tightly controlled since it is driven by the variable and dynamic diversity and expression of BSHs in the gut. Hence, the gut microbiota can be thought of as another environmental factor controlling an up-and-coming endocrine factor that is not stable and influenced by diet and medications.

\section{SCFAs and the endocrine system}

One of the most fundamental contributions that the gut microbiota makes to host function is the provision of SCFAs. These relatively simple molecules, predominantly butyrate, acetate and propionate, are all produced when certain classes of bacteria ferment a variety of carbon sources anaerobically. Although SCFAs are the end products of metabolism for some bacteria, they are a significant source of energy for the host. Both termites
$* * P<0.01 ; * * * P<0.001$ (modified from Swann JR, Want EJ, Geier FM, Spagou K, Wilson ID, Sidaway JE, Nicholson JK \& Holmes E 2011 Systemic gut microbial modulation of bile acid metabolism in host tissue compartments. PNAS 108(Suppl 1) 4523-4530. (doi:10.1073/pnas. 1006734107)). Unconjugated bile acids are those that are produced by bacterial metabolism of the host conjugated acids.

(Warnecke et al. 2007) and ruminants (Brulc et al. 2009) have evolved a mutualistic relationship with the organisms that synthesise SCFAs, and it seems that humans too have co-evolved with these bacterial functions. The G-protein-coupled receptors free fatty acid receptor 2 (FFAR2, GPR43) and FFAR3 (GPR41) are the two endogenous receptors that have been identified to interact with SCFAs (Brown et al. 2003, Le Poul et al. 2003, Nilsson et al. 2003). FFAR2 and FFAR3 interact with the SCFAs ( $\mu \mathrm{M}-\mathrm{mM}$ range) with a carbon chain length greater than six atoms and are those that are most likely to have evolved in response to the fermentation products of the gut bacteria. Both receptors are found in a variety of tissues including the gut and have been shown to be expressed in enteroendocrine cells that are producing peptide YY (PYY; Table 1). SCFAs have been shown to stimulate the release of PYY and 5-hydroxytryptamine (5-HT) from the

Published by Bioscientifica Ltd 
Table 1 Characteristics of free fatty acid receptor 2 and free fatty acid receptor 3

\begin{tabular}{|c|c|}
\hline Nomenclature & FFAR2 \\
\hline Agonist (FFA) & $\begin{array}{l}\text { Short-chain } \\
C 3 \sim C 4 \sim C 2\end{array}$ \\
\hline Gene & GPR43 \\
\hline Localisation & $19 q 13.1$ \\
\hline $\begin{array}{l}\text { Expression outside } \\
\text { of the gut }\end{array}$ & Adipose tissue \\
\hline Physiological role & $\begin{array}{l}\text { PYY secretion } \\
5-\mathrm{HT} \text { secretion }\end{array}$ \\
\hline
\end{tabular}

\section{FFAR3}

Short-chain $\mathrm{C} 3>$

$\mathrm{C} 4 \gg \mathrm{C} 2$

GPR41

$19 q 13.1$

Adipose tissue

Leptin production PYY secretion

ileum and colon (Cherbut et al. 1998, Fukumoto et al. 2003). Mice that have had their FFAR3 knocked out (Samuel et al. 2008) show an associated reduction in the expression of PYY, increased intestinal transit rate and reduced harvest of energy (SCFAs) from the diet. These authors concluded that FFAR3 is involved in the regulation of host energy balance, which is ultimately driven by the gut microbiota and its metabolites. Additionally, the FFARs have been proposed to be involved in glucose intolerance and thus diabetes (Tolhurst et al. 2012). Tolhurst et al. have shown in their study that both FFAR2 and FFAR3 are more greatly expressed in glucagon-like peptide-1 (GLP1)-secreting cells. Additionally, when mice that were homozygous negative for both FFARs were exposed to SCFAs, there was a significant reduction in SCFA-triggered GLP1 secretion. The other significant role that these bacterially derived metabolites play is the stimulation of leptin production in adipocytes (Xiong et al. 2004); however, the exact mechanism is still being elucidated (Zaibi et al. 2010). Since leptin is involved in a wide range of physiological processes, such as feeding behaviour, reproduction and metabolic rate, any molecules that stimulate its production are of significant interest. All of the SCFAs have been shown to stimulate plasma leptin levels (Yonekura et al. 2003, Xiong et al. 2004), and when propionate is delivered orally, these levels are raised and the effect can be blocked by small-interfering RNAs targeted towards GPR41 in Ob-Luc cells (Xiong et al. 2004).

Although SCFAs have been shown to interact with their own cognate receptors, they have also been shown to modulate hepatic glucose production in humans (Thorburn et al. 1993). The intake of fibre, which acts as a prebiotic and is only metabolised by the gut bacteria, has been reported to be inversely associated with the risk of type 2 diabetes and heart disease (Pereira et al. 2002). The hypothesis that fibre is digested eventually to SCFAs is an important one in the area of the gut microbiota, because it

assumes that fibre ingested will be digested to SCFAs and that this leads to eventual benefits to the host. However, this treats the gut microbiota as a 'black box' and does not consider that individuals' capacity to metabolise the different components of the fibre and to ferment these degradation products to SCFAs is conditional on them having the necessary bacterial functions present in the first place. Bearing this in mind, it may be explained why the evidence is not strong as to the beneficial role of fibre in the reduction of the risk of developing diabetes and other diseases (Williams 2012, Caricilli \& Saad 2013).

\section{The brain-gut axis}

The hypothalamic-pituitary-adrenal (HPA) axis has received much attention in recent years, in particular, its association with the gut and its resident microbiota. It is becoming increasingly apparent that this association can both positively and negatively affect host health, with implications for the gut microbiota itself and the endocrine system.

Studies using in vitro and in vivo models have hinted at the possible underlying mechanisms of the effect of stress on the gut through the HPA axis. It has been shown that this axis responds to stress (Herman et al. 2003) through the secretion of corticotropin-releasing hormone (CRH) from the hypothalamus, in turn triggering the release of ACTH from the pituitary gland and driving the release of catecholamines and cortisol from the cortex (Mawdsley \& Rampton 2005). CRH has been shown to stimulate the release of pro-inflammatory cytokines such as TNF $\alpha$, IL1 $\beta$ and IL6 in in vitro and in vivo murine models (Agelaki et al. 2002), while the in vivo stimulation of $\beta$-adrenergic receptor, a receptor for the catecholamines norepinephrine and epinephrine, has been shown to increase the levels of circulating IL1 and IL6 (Johnson et al. 2005). The production of cytokines, in particular, TNF $\alpha$, has been shown to affect the gut epithelial barrier function in both in vitro (Schmitz et al. 1999) and in human studies, where one study has shown the restoration of the gut epithelial barrier function in Crohn's disease patients through the administration of infliximab, a chimeric MAB against TNF $\alpha$ (Suenaert et al. 2002). Bacterial cells can also disrupt the function of the gut epithelial membrane through lipopolysaccharide (LPS) and its interaction with myosin light chain kinase, a regulator of tight junctions (Shen et al. 2006). It has also been shown that the stress response of the HPA axis and 'leakiness' of the gut epithelial barrier in mice can be attenuated through feeding of the probiotic organism Lactobacillus farciminis (Ait-Belgnaoui et al.

Published by Bioscientifica Ltd. 
2012). This highlights the two-way nature of the HPA axis and our resident gut microbiota.

A very common diagnosis in gastroenterological practice worldwide is irritable bowel syndrome (IBS), which is characterised by abnormal bowel function, bloating and abdominal pain or discomfort relieved by defaecation (Spiller et al. 2007). IBS significantly affects quality of life (Simren et al. 2006) and is a substantial economic burden to healthcare systems (Nyrop et al. 2007). IBS has been reported to be present in up to $10 \%$ of the population and responsible for $3.6 \%$ of GP consultations. So, understanding this syndrome is an important goal, and recently, in a landmark study, Dinan et al. (2006) have shown that in an IBS cohort the levels of cortisol and the pro-inflammatory cytokines IL6 and IL8 are elevated. Prior to this study, they had also used a bacterial intervention, in the form of two separate probiotics (Lactobacillus salivarius UCC4331 or Bifidobacterium infantis 35624), and shown that $B$. infantis is able to normalise the IL10:IL12 ratio. Hence, this again leads us to the conclusion that the variable levels of some organisms in the gut may be responsible for diseases/syndromes as they signal to a variety of host effectors.

\section{Microbially derived endocrine molecules}

Endocrine molecules are not solely produced by the human body; gut microbes can also produce these molecules. It has been shown previously that there is a significant level of dopamine production in the human gut (Eisenhofer et al. 1997). The importance of the gut microbiota in the generation of this compound has been overlooked, and in a subsequent piece of work, it has been shown that the gut microbiota plays a critical role in the production of norepinephrine and dopamine in the gut (Asano et al. 2012). This production is due to the expression of $\beta$-glucuronidases by commensal gut bacteria, generating dopamine and norepinephrine through the cleavage of their inactive conjugated forms. Gut microbes can also produce non-noradrenergic, non-cholinergic transmitters such as nitric oxide, which plays a pivotal role in the regulation of gastric emptying (Orihata \& Sarna 1994), through the anaerobic reduction of nitrate to nitrogen (Sobko et al. 2005, Cutruzzolà 2012). The inhibitory transmitter $\gamma$-aminobutyric acid can be generated by Lactobacillus brevis and Bifidobacterium dentium (Barrett et al. 2012); both of these organisms can be isolated from humans (Rönkäet al. 2003, Ventura et al. 2009). Studies such as these are highlighting the previously unrealised importance of our own gut microbiota in generating compounds that interact with our own endocrine system.

\section{Diabetes and gut bacteria}

Diabetes is a chronic metabolic disorder that affects an estimated 347 million people throughout the world (WHO 2012). Type 1 diabetes, also known as juvenile diabetes, is a state of absolute deficiency of insulin, while type 2 diabetes is a state of relative insulin deficiency in the presence of obesity and insulin resistance; the prevalence of the latter is increasing among children due to the adoption of a sedentary lifestyle. There is increasing evidence that the gut microbiota plays a role in the development of this disorder. In the non-obese diabetic (NOD) murine model, which was also deficient for the adapter protein MYD88, researchers have shown that the gut microbiota plays a role in the development of type 1 diabetes (Wen et al. 2008). In this study, the islets of Langherans of germ-free, specific pathogen-free and altered Schaedler flora (Dewhirst et al. 1999) Myd88 knockout NOD mice were histologically compared; the germ-free mice exhibited a greater level of islet infiltration. The authors showed that the gut commensal bacteria can modify the development of this disease. With this in mind, research has been carried out to determine which bacterial species and groups in humans are most prevalent in the sufferers of type 1 diabetes. In a recent study (Giongo et al. 2011), the distal gut microbiota of four children with autoimmunity, who went on to develop type 1 diabetes, has been compared with that of four healthy children through pyrosequencing of faecal DNA extracted at three time points. The results highlighted differences between the two major phyla in the gut, Bacteroidetes and Firmicutes. There was an increase in the number of DNA sequences from the Bacteroidetes phylum as autoimmunity developed to type 1 diabetes and a reduction in the number of DNA sequences obtained from the Firmicutes phylum. In contrast, the four healthy children exhibited the opposite pattern, with the number of Bacteroidetes sequences decreasing and that of Firmicutes sequences increasing as each time point was analysed. It was also shown that the healthy control children had a higher diversity of bacterial species than the children with autoimmunity, suggesting a link between low bacterial species diversity and type 1 diabetes. This low diversity is indicative of a non-normal gut microbiota, which has been suggested to combine with intestinal leakiness and altered intestinal immune responsiveness to generate a 'perfect storm' for the development of type 1 diabetes (Vaarala et al. 2008).

The gut microbiota, through LPS, has been shown to exert a pro-inflammatory effect and when combined with

Published by Bioscientifica Ltd 
a high-fat diet leads to the onset of insulin resistance and, therefore, the development of type 2 diabetes in a mouse model (Cani et al. 2007, 2008). In accordance with what has been observed in type 1 diabetes, a metagenomic analysis of faecal samples of type 2 diabetes sufferers has shown a slight level of dysbiosis in their gut bacterial make-up; type 2 diabetes sufferers exhibited higher levels of opportunistic pathogens (Qin et al. 2012). Arguably more important is the fact that this research showed a reduction in the number of butyrate-producing bacteria, a SCFA that modulates the activity of NF- $\kappa \mathrm{B}$ (Inan et al. 2000), hinting that the loss of bacterial species may not be as important as the loss of functions that they play.

\section{Microbial modulation of neurotransmitters: serotonin}

One metabolic pathway of interest is the metabolism of tryptophan, a precursor for a number of metabolites, but particularly for the production of serotonin or 5-HT. Serotonin is a well-documented monoamine neurotransmitter that has been extensively studied due to its hypothesised role in the regulation of learning, mood, sleep, anxiety and other psychiatry-related afflictions. In recent years, serotonin has also gained increasing interest for its role in the area of gut pathophysiology (Gershon \& Tack 2007) and its role as a signalling molecule linking the brain and the gut. Research has been fairly conclusive in demonstrating that bacteria can affect serotonin levels indirectly by stimulating secretion. However, recent evidence suggests a role for the gut microbiota in actually modulating the levels of the serotonin precursor tryptophan and hence having a control over serotonin levels in the host. Research by Desbonnet et al. (2008) has suggested a role for tryptophan producers such as $B$. infantis as probiotics specifically to aid in combating psychiatric disorders such as depression. Other groups have also shown a role for bacteria in modulating neurotransmitter precursors (Rhee et al. 2009, Wikoff et al. 2009, Heijtz et al. 2011).

Around $90 \%$ of serotonin is located in the enterochromaffin cells of the human gastrointestinal tract (Keszthelyi et al. 2009) and, therefore, must be intimately associated with the gastrointestinal mucosa and its microbiota. Enterochromaffin cells release serotonin in response to certain bacterial stimuli such as LPS, enzymes and other bacterial toxins to help increase gastric transit and rid the host of the toxin as quickly as possible (result is often diarrhoea). As a result of a bacterial stimulus, there is release of serotonin, which acts as a signalling molecule to activate primary sensory neurons to communicate with the brain and ultimately alter secretory reflexes. Consequently, an ongoing brain-gut interaction is developed, exerting various effects on gut physiology. This relationship has resulted in serotonin potentially being one of the most significant molecules related to the pathophysiology of intestinal disorders such as inflammatory bowel disease and IBS and is also intrinsically linked to the anxiety and depression associated with such disorders.

If serotonin is in charge of mood and sleep and low levels are associated with the onset of depression, etc., then varying levels of its precursor, tryptophan, are likely to have an effect on available serotonin levels (Heijtz et al. 2011). Studies have shown that germ-free rats have depleted levels of tryptophan, but upon administration of certain bacteria, such as bifidobacterial species, tryptophan levels are increased (Desbonnet et al. 2008), thus suggesting that bacteria can alter the available serotonin pool and ultimately elicit communication between the gut and the brain. Some microbes, such as Candida spp., Streptococcus spp., Escherichia spp. and Enterococcus spp., have been shown to directly produce serotonin (Cryan \& Dinan, 2012), although much more research is needed into the impact that this has on the host.

\section{Conclusions}

In the last decade, the paradigm that the human genome is the predominant driver of host health has shifted towards a more superorganism-based viewpoint, with the microbiome playing a significant role in influencing host physiology and function. This review has not sought to cover all the areas where there is evidence for a role of the host's microbiota and has unapologetically focused on the gut microbiota, since the gut is the best-studied and most densely populated niche. There are numerous other niches in the human body that are colonised and in which the adapted microbiome interacts with the host, and in due course, these will be explored and their interactions with the host described. We hope to have made it more obvious to the reader that the microbiome needs to be understood in more depth and integrated into the endocrine system as it is being integrated into the immune system. In the future, more 'omic' approaches will further uncover more associations between the human microbiome and the endocrine system, which may be drugable and thus modulated to the benefit of the host.

\section{Declaration of interest}

The authors declare that there is no conflict of interest that could be perceived as prejudicing the impartiality of the review.

Published by Bioscientifica Ltd. 


\section{Funding}

This research did not receive any specific grant from any funding agency in the public, commercial or not-for-profit sector.

\section{Author contribution statement}

All authors contributed equally to the writing of this manuscript.

\section{Acknowledgements}

The authors thank the BBSRC (for funding L S M's studentship) and Knowledge Economy Skills Scholarships (KESS; for funding J M E's studentship).

\section{References}

Agelaki S, Tsatsanis C, Gravanis A \& Margioris AN 2002 Corticotropinreleasing hormone augments proinflammatory cytokine production from macrophages in vitro and in lipopolysaccharide-induced endotoxin shock in mice. Infection and Immunity 70 6068-6074. (doi:10.1128/IAI.70.11.6068-6074.2002)

Ait-Belgnaoui A, Durand H, Cartier C, Chaumaz G, Eutamene H, Ferrier L, Houdeau E, Fioramonti J, Bueno L \& Theodorou V 2012 Prevention of gut leakiness by a probiotic treatment leads to attenuated HPA response to an acute psychological stress in rats. Psychoneuroendocrinology 37 1885-1895. (doi:10.1016/j.psyneuen.2012.03.024)

Asano Y, Hiramoto T, Nishino R, Aiba Y, Kimura T, Yoshihara K, Koga Y \& Sudo N 2012 Critical role of gut microbiota in the production of biologically active, free catecholamines in the gut lumen of mice. American Journal of Physiology. Gastrointestinal and Liver Physiology 303 G1288-G1295. (doi:10.1152/ajpgi.00341.2012)

Barrett E, Ross RP, O’Toole PW, Fitzgerald GF \& Stanton C 2012 $\gamma$-Aminobutyric acid production by culturable bacteria from the human intestine. Journal of Applied Microbiology 113 411-417. (doi:10.1111/j.1365-2672.2012.05344.x)

Brown AJ, Goldsworthy SM, Barnes AA, Eilert MM, Tcheang L, Daniels D, Muir AI, Wigglesworth MJ, Kinghorn I, Fraser NJ et al. 2003 The orphan G protein-coupled receptors GPR41 and GPR43 are activated by propionate and other short chain carboxylic acids. Journal of Biological Chemistry 278 11312-11319. (doi:10.1074/jbc.M211609200)

Brulc JM, Antonopoulos DA, Miller ME, Wilson MK, Yannarell AC, Dinsdale EA, Edwards RE, Frank ED, Emerson JB, Wacklin P et al. 2009 Gene-centric metagenomics of the fiber-adherent bovine rumen microbiome reveals forage specific glycoside hydrolases. PNAS 106 1948-1953. (doi:10.1073/pnas.0806191105)

Cani PD, Amar J, Iglesias MA, Poggi M, Knauf C, Bastelica D, Neyrinck AM, Fava F, Tuohy KM, Chabo C et al. 2007 Metabolic endotoxemia initiates obesity and insulin resistance. Diabetes 56 1761-1772. (doi:10.2337/ db06-1491)

Cani PD, Bibiloni R, Knauf C, Waget A, Neyrinck AM, Delzenne NM \& Burcelin R 2008 Changes in gut microbiota control metabolic endotoxemia-induced inflammation in high-fat diet-induced obesity and diabetes in mice. Diabetes 57 1470-1481. (doi:10.2337/db07-1403)

Caricilli AM \& Saad MJA 2013 The role of gut microbiota on insulin resistance. Nutrients 5 829-851. (doi:10.3390/nu5030829)

Chen W, Liu F, Ling Z, Tong X \& Xiang C 2012 Human intestinal lumen and mucosa-associated microbiota in patients with colorectal cancer. PLOS ONE 7 e39743. (doi:10.1371/journal.pone.0039743)

Cherbut C, Ferrier L, Roze C, Anini Y, Blottiere H, Lecannu G \& Galmiche JP 1998 Short-chain fatty acids modify colonic motility through nerves and polypeptide YY release in the rat. American Journal of Physiology 275 G1415-G1422.
Claesson MJ, Cusack S, O'Sullivan O, Greene-Diniz R, de Weerd H, Flannery E, Marchesi JR, Falush D, Dinan T, Fitzgerald G et al. 2011 Composition, variability, and temporal stability of the intestinal microbiota of the elderly. PNAS 108 4586-4591. (doi:10.1073/pnas.1000097107)

Claesson MJ, Jeffery IB, Conde S, Power SE, O'Connor EM, Cusack S, Harris HMB, Coakley M, Lakshminarayanan B, O'Sullivan O et al. 2012 Gut microbiota composition correlates with diet and health in the elderly. Nature 488 178-184. (doi:10.1038/nature11319)

Collins FS, Lander ES, Rogers J \& Waterson RH 2004 Finishing the euchromatic sequence of the human genome. Nature 431 931-945. (doi:10.1038/nature02945)

Collins SM, Surette M \& Bercik P 2012 The interplay between the intestinal microbiota and the brain. Nature Reviews. Microbiology 10 735-742. (doi:10.1038/nrmicro2876)

Cryan JF \& Dinan TG 2012 Mind-altering microorganisms: the impact of the gut microbiota on brain and behaviour. Nature Reviews. Neuroscience 13 701-712. (doi:10.1038/nrn3346)

Cutruzzolà F 2012 Nitric oxide synthesis by bacterial cytochrome cd1 nitrite reductases. Nitric Oxide 27(Suppl) S10. (doi:10.1016/j.niox.2012. 04.037)

Desbonnet L, Garrett L, Clarke G, Bienenstock J \& Dinan TG 2008 The probiotic Bifidobacterium infantis: an assessment of potential antidepressant properties in the rat. Journal of Psychiatric Research 43 164-174. (doi:10.1016/j.jpsychires.2008.03.009)

Dethlefsen L, Huse S, Sogin ML \& Relman DA 2008 The pervasive effects of an antibiotic on the human gut microbiota, as revealed by deep $16 \mathrm{~S}$ rRNA sequencing. PLoS Biology 6 e280. (doi:10.1371/journal.pbio. 0060280)

Dewhirst FE, Chien CC, Paster BJ, Ericson RL, Orcutt RP, Schauer DB \& Fox JG 1999 Phylogeny of the defined murine microbiota: altered Schaedler flora. Applied and Environmental Microbiology 65 3287-3292.

Dinan TG, Quigley EMM, Ahmed SMM, Scully P, O'Brien S, O'Mahony L, O'Mahony S, Shanahan F \& Keeling PWN 2006 Hypothalamicpituitary-gut axis dysregulation in irritable bowel syndrome: plasma cytokines as a potential biomarker? Gastroenterology 130 304-311. (doi:10.1053/j.gastro.2005.11.033)

Eckburg PB, Bik EM, Bernstein CN, Purdom E, Dethlefsen L, Sargent M, Gill SR, Nelson KE \& Relman DA 2005 Diversity of the human intestinal microbial flora. Science 308 1635-1638. (doi:10.1126/science.1110591)

Eisenhofer G, Aneman A, Friberg P, Hooper D, Fandriks L, Lonroth H, Hunyady B \& Mezey E 1997 Substantial production of dopamine in the human gastrointestinal tract. Journal of Clinical Endocrinology and Metabolism 82 3864-3871. (doi:10.1210/jc.82.11.3864)

Fischbach MA \& Sonnenburg JL 2011 Eating for two: how metabolism establishes interspecies interactions in the gut. Cell Host \& Microbe 10 336-347. (doi:10.1016/j.chom.2011.10.002)

Fukumoto S, Tatewaki M, Yamada T, Fujimiya M, Mantyh C, Voss M, Eubanks S, Harris M, Pappas TN \& Takahashi T 2003 Short-chain fatty acids stimulate colonic transit via intraluminal 5-HT release in rats. American Journal of Physiololgy. Regulatory, Integrative and Comparative Physiology 284 R1269-R1276.

Gershon MD \& Tack J 2007 The serotonin signaling system: from basic understanding to drug development for functional GI disorders. Gastroenterology 132 397-414. (doi:10.1053/j.gastro.2006.11.002)

Giongo A, Gano KA, Crabb DB, Mukherjee N, Novelo LL, Casella G, Drew JC, Ilonen J, Knip M, Hyöty H et al. 2011 Toward defining the autoimmune microbiome for type 1 diabetes. ISME Journal 5 82-91. (doi:10.1038/ ismej.2010.92)

Harrell L, Wang Y, Antonopoulos D, Young V, Lichtenstein L, Huang Y, Hanauer S \& Chang E 2012 Standard colonic lavage alters the natural state of mucosal-associated microbiota in the human colon. PLOS ONE 7 e32545. (doi:10.1371/journal.pone.0032545)

Heijtz RD, Wang S, Anuar F, Qian Y, Björkholm B, Samuelsson A, Hibberd ML, Forssberg H \& Pettersson S 2011 Normal gut microbiota modulates brain development and behavior. PNAS 108 3047-3052. (doi:10.1073/pnas. 1010529108) 
Herman JP, Figueiredo H, Mueller NK, Ulrich-Lai Y, Ostrander MM, Choi DC \& Cullinan WE 2003 Central mechanisms of stress integration: hierarchical circuitry controlling hypothalamo-pituitaryadrenocortical responsiveness. Frontiers in Neuroendocrinology 24 151-180. (doi:10.1016/j.yfrne.2003.07.001)

Human Microbiome Project Consortium (HMPC) , Huttenhower C, Gevers D, Knight R, Abubucker S, Badger JH, Chinwalla AT, Creasy HH, Earl AM, FitzGerald MG et al. 2012 Structure function and diversity of the healthy human microbiome. Nature 486 207-214. (doi:10.1038/nature11234)

Inan MS, Rasoulpour RJ, Yin L, Hubbard AK, Rosenberg DW \& Giardina C 2000 The luminal short-chain fatty acid butyrate modulates NF- $\kappa$ B activity in a human colonic epithelial cell line. Gastroenterology 118 724-734. (doi:10.1016/S0016-5085(00)70142-9)

Jalanka-Tuovinen J, Salonen A, Nikkilä J, Immonen O, Kekkonen R, Lahti L, Palva A \& de Vos WM 2011 Intestinal microbiota in healthy adults: temporal analysis reveals individual and common core and relation to intestinal symptoms. PLoS ONE 6 e23035. (doi:10.1371/journal.pone. 0023035)

Jernberg C, Löfmark S, Edlund C \& Jansson JK 2010 Long-term impacts of antibiotic exposure on the human intestinal microbiota. Microbiology 156 3216-3223. (doi:10.1099/mic.0.040618-0)

Johnson JD, Campisi J, Sharkey CM, Kennedy SL, Nickerson M, Greenwood BN \& Fleshner M 2005 Catecholamines mediate stressinduced increases in peripheral and central inflammatory cytokines. Neuroscience 135 1295-1307. (doi:10.1016/j.neuroscience.2005.06. 090)

Jones BV, Begley M, Hill C, Gahan CGM \& Marchesi JR 2008 Functional and comparative metagenomic analysis of bile salt hydrolase activity in the human gut microbiome. PNAS 105 13580-13585. (doi:10.1073/ pnas.0804437105)

Kachrimanidou M \& Malisiovas N 2011 Clostridium difficile infection: a comprehensive review. Critical Reviews in Microbiology 37 178-187. (doi:10.3109/1040841X.2011.556598)

Keszthelyi D, Troost FJ \& Masclee AAM 2009 Understanding the role of tryptophan and serotonin metabolism in gastrointestinal function. Neurogastroenterology and Motility 21 1239-1249. (doi:10.1111/j.13652982.2009.01370.x)

Koenig JE, Spor A, Scalfone N, Fricker AD, Stombaugh J, Knight R, Angenent LT \& Ley RE 2011 Succession of microbial consortia in the developing infant gut microbiome. PNAS 108 4578-4585. (doi:10.1073/pnas.1000081107)

Kolmeder CA, de Been M, Nikkilä J, Ritamo I, Mättö J, Valmu L, Salojärvi J, Palva A, Salonen A \& de Vos WM 2012 Comparative metaproteomics and diversity analysis of human intestinal microbiota testifies for its temporal stability and expression of core functions. PLOS ONE 7 e29913. (doi:10.1371/journal.pone.0029913)

Le Poul E, Loison C, Struyf S, Springael JY, Lannoy V, Decobecq ME, Brezillon S, Dupriez V, Vassart G, Van Damme J et al. 2003 Functional characterization of human receptors for short chain fatty acids and their role in polymorphonuclear cell activation. Journal of Biological Chemistry 278 25481-25489. (doi:10.1074/jbc.M301403200)

Li JV, Ashrafian H, Bueter M, Kinross J, Sands C, le Roux CW, Bloom SR, Darzi A, Athanasiou T, Marchesi JR et al. 2011 Metabolic surgery profoundly influences gut microbial-host metabolic cross-talk. Gut 60 1214-1223. (doi:10.1136/gut.2010.234708)

Louis P \& Flint HJ 2009 Diversity, metabolism and microbial ecology of butyrate-producing bacteria from the human large intestine. FEMS Microbiology Letters 294 1-8. (doi:10.1111/j.1574-6968.2009.01514.x)

Macfarlane GT \& Macfarlane S 2011 Fermentation in the human large intestine: Its physiologic consequences and the potential contribution of prebiotics. Journal of Clinical Gastroenterology 45 S120-S127. (doi:10.1097/MCG.0b013e31822fecfe)

Marchesi JR 2010 Prokaryotic and eukaryotic diversity of the human gut. Advances in Applied Microbiology 72 43-62.
Mawdsley JE \& Rampton DS 2005 Psychological stress in IBD: new insights into pathogenic and therapeutic implications. Gut 54 1481-1491. (doi:10.1136/gut.2005.064261)

Nilsson NE, Kotarsky K, Owman C \& Olde B 2003 Identification of a free fatty acid receptor, FFA2R, expressed on leukocytes and activated by short-chain fatty acids. Biochemical and Biophysical Research Communications 303 1047-1052. (doi:10.1016/S0006-291X(03)00488-1)

Nyrop KA, Palsson OS, Levy RL, Korff MV, Feld AD, Turner MJ \& Whitehead WE 2007 Costs of health care for irritable bowel syndrome, chronic constipation, functional diarrhoea and functional abdominal pain. Alimentary Pharmacology \& Therapeutics 26 237-248. (doi:10.1111/j.1365-2036.2007.03370.x)

O'Hara AM \& Shanahan F 2006 The gut flora as a forgotten organ. EMBO Reports 7 688-693. (doi:10.1038/sj.embor.7400731)

Orihata M \& Sarna SK 1994 Inhibition of nitric oxide synthase delays gastric emptying of solid meals. Journal of Pharmacology and Experimental Therapeutics 271 660-670.

Pennisi E 2003 A low number wins the GeneSweep pool. Science 3001484. (doi:10.1126/science.300.5625.1484b)

Pereira MA, Jacobs DR, Pins JJ, Raatz SK, Gross MD, Slavin JL \& Seaquist ER 2002 Effect of whole grains on insulin sensitivity in overweight hyperinsulinemic adults. American Journal of Clinical Nutrition $\mathbf{7 5}$ 848-855.

Qin J, Li R, Raes J, Arumugam M, Burgdorf KS, Manichanh C, Nielsen T, Pons N, Levenez F, Yamada T et al. 2010 A human gut microbial gene catalogue established by metagenomic sequencing. Nature 464 59-65. (doi:10.1038/nature08821)

Qin JJ, Li YR, Cai ZM, Li SH, Zhu JF, Zhang F, Liang SS, Zhang WW, Guan YL , Shen DQ et al. 2012 A metagenome-wide association study of gut microbiota in type 2 diabetes. Nature 490 55-60. (doi:10.1038/ nature11450)

Ravussin Y, Koren O, Spor A, Leduc C, Gutman R, Stombaugh J, Knight R, Ley RE \& Leibel RL 2012 Responses of gut microbiota to diet composition and weight loss in lean and obese mice. Obesity 20 738-747. (doi:10.1038/oby.2011.111)

Rhee SH, Pothoulakis C \& Mayer EA 2009 Principles and clinical implications of the brain-gut-enteric microbiota axis. Nature Reviews. Gastroenterology and Hepatology 6 306-314. (doi:10.1038/nrgastro. 2009.35)

Rönkä E, Malinen E, Saarela M, Rinta-Koski M, Aarnikunnas J \& Palva A 2003 Probiotic and milk technological properties of Lactobacillus brevis. International Journal of Food Microbiology 83 63-74. (doi:10.1016/S01681605(02)00315-X)

Russell DW 2003 The enzymes, regulation and genetics of bile acid synthesis. Annual Review of Biochemistry 72 137-174. (doi:10.1146/ annurev.biochem.72.121801.161712)

Samuel BS, Shaito A, Motoike T, Rey FE, Backhed F, Manchester JK, Hammer RE, Williams SC, Crowley J, Yanagisawa M et al. 2008 Effects of the gut microbiota on host adiposity are modulated by the short-chain fatty-acid binding G protein-coupled receptor, Gpr41. PNAS 105 16767-16772. (doi:10.1073/pnas.0808567105)

Scanlan PD, Shanahan F, O'Mahony C \& Marchesi JR 2006 Cultureindependent analyses of the temporal variation of the dominant faecal microbiota and targeted bacterial sub-groups in Crohn's disease. Journal of Clinical Microbiology 44 3980-3988. (doi:10.1128/JCM. 00312-06)

Schmitz H, Fromm M, Bentzel CJ, Scholz P, Detjen K, Mankertz J, Bode H, Epple HJ, Riecken EO \& Schulzke JD 1999 Tumor necrosis factor- $\alpha$ $(\mathrm{TNF} \alpha)$ regulates the epithelial barrier in the human intestinal cell line HT-29/B6. Journal of Cell Science 112 137-146.

Shen L, Black ED, Witkowski ED, Lencer WI, Guerriero V, Schneeberger EE \& Turner JR 2006 Myosin light chain phosphorylation regulates barrier function by remodeling tight junction structure. Journal of Cell Science 119 2095-2106. (doi:10.1242/jcs.02915)

Simren M, Svedlund J, Posserud I, Bjornsson ES \& Abrahamsson H 2006 Health-related quality of life in patients attending a gastroenterology 
outpatient clinic: functional disorders versus organic diseases. Clinical Gastroenterology and Hepatology 4 187-195. (doi:10.1016/S15423565(05)00981-X)

Smith K, McCoy KD \& Macpherson AJ 2007 Use of axenic animals in studying the adaptation of mammals to their commensal intestinal microbiota. Seminars in Immunology 19 59-69. (doi:10.1016/j.smim. 2006.10.002)

Sobko T, Reinders CI, Jansson EÅ, Norin E, Midtvedt T \& Lundberg JO 2005 Gastrointestinal bacteria generate nitric oxide from nitrate and nitrite. Nitric Oxide 13 272-278. (doi:10.1016/j.niox.2005.08.002)

Spiller R, Aziz Q, Creed F, Emmanuel A, Houghton L, Hungin P, Jones R, Kumar D, Rubin G, Trudgill N et al. 2007 Guidelines on the irritable bowel syndrome: mechanisms and practical management. Gut $\mathbf{5 6}$ 1770-1798. (doi:10.1136/gut.2007.119446)

Suenaert P, Bulteel V, Lemmens L, Noman M, Geypens B, Assche GV, Geboes K, Ceuppens JL \& Rutgeerts P 2002 Anti-tumor necrosis factor treatment restores the gut barrier in Crohn's disease. American Journal of Gastroenterology 97 2000-2004. (doi:10.1111/j.1572-0241. 2002.05914.x)

Swann JR, Want EJ, Geier FM, Spagou K, Wilson ID, Sidaway JE, Nicholson JK \& Holmes E 2011 Systemic gut microbial modulation of bile acid metabolism in host tissue compartments. PNAS 108(Suppl 1) 4523-4530. (doi:10.1073/pnas.1006734107)

Thorburn A, Muir J \& Proietto J 1993 Carbohydrate fermentation decreases hepatic glucose output in healthy subjects. Metabolism 42 780-785. (doi:10.1016/0026-0495(93)90249-N)

Tims S, Derom C, Jonkers DM, Vlietinck R, Saris WH, Kleerebezem M, de Vos WM \& Zoetendal EG 2013 Microbiota conservation and BMI signatures in adult monozygotic twins. ISME Journal 7 707-717. (doi:10.1038/ismej.2012.146)

Tolhurst G, Heffron H, Lam YS, Parker HE, Habib AM, Diakogiannaki E, Cameron J, Grosse J, Reimann F \& Gribble FM 2012 Short-chain fatty acids stimulate glucagon-like peptide-1 secretion via the G-proteincoupled receptor FFAR2. Diabetes 61 364-371. (doi:10.2337/db11-1019)

Turnbaugh PJ, Hamady M, Yatsunenko T, Cantarel BL, Duncan A, Ley RE, Sogin ML, Jones WJ, Roe BA, Affourtit JP et al. 2009 A core gut microbiome in obese and lean twins. Nature $\mathbf{4 5 7} 480-484$. (doi:10.1038/nature07540)

Vaarala O, Atkinson MA \& Neu J 2008 The 'perfect storm' for type 1 diabetes: the complex interplay between intestinal microbiota, gut permeability, and mucosal immunity. Diabetes 57 2555-2562. (doi:10.2337/db08-0331)

Ventura M, Turroni F, Zomer A, Foroni E, Giubellini V, Bottacini F, Canchaya C, Claesson MJ, He F, Mantzourani M et al. 2009 The Bifidobacterium dentium $\mathrm{Bd} 1$ genome sequence reflects its genetic adaptation to the human oral cavity. PLoS Genetics 5 e1000785. (doi:10.1371/journal.pgen.1000785)

Warnecke F, Luginbuhl P, Ivanova N, Ghassemian M, Richardson TH, Stege JT, Cayouette M, McHardy AC, Djordjevic G, Aboushadi N et al. 2007 Metagenomic and functional analysis of hindgut microbiota of a woodfeeding higher termite. Nature 450 560-565. (doi:10.1038/ nature06269)

Wen L, Ley RE, Volchkov PY, Stranges PB, Avanesyan L, Stonebraker AC, Hu C, Wong FS, Szot GL, Bluestone JA et al. 2008 Innate immunity and intestinal microbiota in the development of type 1 diabetes. Nature $\mathbf{4 5 5}$ 1109-1113. (doi:10.1038/nature07336)

WHO 2012 Diabetes. World Health Organisation. Available at: http://www. who.int/mediacentre/factsheets/fs312/en/index.html [Accessed: 29/ $11 / 2012]$

Wikoff WR, Anfora AT, Liu J, Schultz PG, Lesley SA, Peters EC \& Siuzdak G 2009 Metabolomics analysis reveals large effects of gut microflora on mammalian blood metabolites. PNAS 106 3698-3703. (doi:10.1073/ pnas.0812874106)

Williams PG 2012 Evaluation of the evidence between consumption of refined grains and health outcomes. Nutrition Reviews 70 80-99. (doi:10. 1111/j.1753-4887.2011.00452.x)

Xiong Y, Miyamoto N, Shibata K, Valasek MA, Motoike T, Kedzierski RM \& Yanagisawa M 2004 Short-chain fatty acids stimulate leptin production in adipocytes through the $\mathrm{G}$ protein-coupled receptor GPR41. PNAS 101 1045-1050. (doi:10.1073/pnas.2637002100)

Yap IK, Li JV, Saric J, Martin FP, Davies H, Wang Y, Wilson ID, Nicholson JK, Utzinger J, Marchesi JR et al. 2008 Metabonomic and microbiological analysis of the dynamic effect of vancomycin-induced gut microbiota modification in the mouse. Journal of Proteome Research 7 3718-3728. (doi:10.1021/pr700864x)

Yonekura S, Senoo T, Kobayashi Y, Yonezawa T, Katoh K \& Obara Y 2003 Effects of acetate and butyrate on the expression of leptin and shortform leptin receptor in bovine and rat anterior pituitary cells. General and Comparative Endocrinology 133 165-172. (doi:10.1016/S00166480(03)00162-X)

Zaibi MS, Stocker CJ, O'Dowd J, Davies A, Bellahcene M, Cawthorne MA, Brown AJH, Smith DM \& Arch JRS 2010 Roles of GPR41 and GPR43 in leptin secretory responses of murine adipocytes to short chain fatty acids. FEBS Letters 584 2381-2386. (doi:10.1016/j.febslet.2010. 04.027)

Zhang H, Dibaise JK, Zuccolo A, Kudrna D, Braidotti M, Yu Y, Parameswaran P, Crowell MD, Wing R, Rittmann BE et al. 2009 Human gut microbiota in obesity and after gastric bypass. PNAS 106 2365-2370. (doi:10.1073/pnas.0812600106)

Received in final form 3 July 2013

Accepted 5 July 2013

Accepted Preprint published online 5 July 2013 http://joe.endocrinology-journals.org DOI: 10.1530/JOE-13-0131
(ㄷ) 2013 Society for Endocrinology Printed in Great Britain
Published by Bioscientifica Ltd. 